\title{
Cytomorphology of Circulating Tumor Cells and Cell Clusters in Chilean Patients with Colo-Rectal Cancer
}

\author{
Citomorfología de las Células Tumorales Circulantes y Células Agrupadas \\ en Pacientes Chilenos con Cáncer Colo-rectal
}

*,**,***N Nigel P. Murray; "Vidal Albarran R-C.; *Guillermo Pérez O.; *Amparo Ruiz M.; "José Porcell E. \& *Ana María Castillo A.

MURRAY, N. P.; ALBARRAN, R-C. V.; PÉREZ, O. G.; RUIZ, M. A.; PORCELL, E. J. \& CASTILLO, A. A. M. Cytomorphology of circulating tumor cells and cell clusters in Chilean patients with colo-rectal cancer. Int. J. Morphol., 30(3):834-839, 2012.

SUMMARY: The aim of this study was to determine the cytomorphological characteristics of circulating tumor cells (CTCS) in patients with colo-rectal cancer and compare them with the primary tumor and metastasis. CTCS were obtained from blood using differential gel centrifugation and detected using standard immunocytochemistry using anti-CEA. Primary CTCs were defined as those detected before surgery and secondary CTCs those detected after. Surgical specimens of the primary tumor and metastasis were evaluated using standard histological methods with hematoxillin and eosin. CTCs both primary and secondary retained the cytomorphological characteristics of the primary tumor, showing marked intra-patient pleomorphism. There were no differences between primary and secondary CTCs in their cytomorphological features. CTCs from patients with signet ring tumors showed the presence of intracellular mucin deposits. Groups of 3 or more CTCs were only seen in patients with metastasis, whereas duplets of CTcs were seen in patients with metastatic and non-metastatic colo-rectal cancer. This study provides an initial analysis of the cytomorphological features of CTCs, providing a foundation for further investigation into the significance and metastatic potential of CTCs.

KEY WORDS: Circulating tumor cells; Colo-rectal cancer; Immunocytochemistry.

\section{INTRODUCTION}

The dissemination of cancer cells from the primary tumor site to distant tissues is an early event in the malignant process. These circulating tumor cells can be detected in the blood of patients with colo-rectal cancer (CRC) before the development of metastasis (Glaves, 1983). Circulating tumor cells (CTCs) have been detected in the peripheral blood of patients with a variety of metastatic solid tumors at varying concentrations using a variety of methods, such as RT-PCR, immunocytochemistry, immunoflorescence and flow cytometry (Jonas et al., 1996: Nagrath et al., 2007: Sastre et al., 2008: Marrinucci et al., 2010). The majority of these cells will die, it has been estimated that fewer than $0.01 \%$ of CTCs will implant and form metastasis (Fidler, 1973), and most CTCs are cleared from the circulation within 24 hours (Fidler, 1970).

One limitation of RT-PCR and flow cytometry is the lack of morphological confirmation of a cellular structure or if these cells are found as single cells or in groups (clusters). This is important, as the identification of circulating cell clusters may infer a worse prognosis (Molnar et al., 2001). For morphologically intact circulating tumor cell detection, the microscopic evaluation of immunocytochemically labeled cells was preferred (Leather et al., 1993). Most CTC detection methods depend on cell enrichment, differential gel centrifugation or immunomagnetic separation and then immunoflorescent or immunocytochemical labeling with epithelial specific antigens such as epithelial cell adhesion molecule (EpCAM) or cytokeratin. However because of methodological limitations cytological details of the detected cells are not discernible. Therefore it is important that the enumeration of CTCs should be evaluated together with the morphological characteristics.

The aim of the present study was to evaluate whether using standard differential gel centrifugation and immunocytochemical analysis of circulating tumor cells in Chilean patients with colo-rectal cancer produces clinically useful data.

\footnotetext{
" Hospital de Carabineros de Chile, Santiago, Chile.

** Facultad de Medicina, Universidad Mayor, Santiago, Chile.

**** Instututo de Bio-Oncología, Santiago, Chile.
} 


\section{PATIENTS AND METHOD}

Patients with histologically confirmed colo-rectal cancer attending the Colo-proctology Department, Hospital de Carabineros de Chile, Santiago between April 2008 and December 2011 participated in the study. 10 patients with normal colonoscopy participated as controls.

After written informed consent, as approved by the Hospital Ethics Committee, an $8 \mathrm{ml}$ blood sample was collected into EDTA (Beckinson-Vacutainer®). Samples were processed within 24 hours, being stored at $4^{\circ} \mathrm{C}$ prior to processing. The samples were layered onto $2 \mathrm{ml}$ Histopaque 1.077® (Sigma-Aldrich) at room temperature, and the mononuclear cells obtained according to manufacturer's instructions and finally washed 3 times in phosphate buffered saline $\mathrm{pH} 7.4$ (PBS). The pellet was resuspended in $100 \mathrm{ml}$ of autologous plasma and $25 \mathrm{ml}$ used to prepare each slide (silanized DAKO, USA). The slides were air dried for 24 hours at room temperature and finally fixed in a solution of $70 \%$ ethanol, $5 \%$ formaldehyde and $25 \%$ PBS for 5 minutes and then washed 3 times with PBS.

Immunocytochemical staining protocol for labeling CTCs: Monoclonal antibodies directed against carcino-embrionic antigen (CEA), cloneII-7 (DAKO, USA) in a dilution of 1:100 were used to detect colorectal cells, and identified using a detection system based on alkaline phosphatase-antialkaline phosphatase (LSAB2 DAKO, USA) with new-fuchsin as the chromogen (according to the manufacturer's instructions). To permit the rapid identification of positive cells there was no counter staining with Mayer's hematoxillin. Levisamole (DAKO, USA) was used as an inhibitor of endogenous alkaline phosphatase, with positive and negative controls.

Samples were evaluated using 20X magnification to identify and count CTCs. For morphological evaluation 100X magnification was used and microphotographs taken with a digital camera and processed using the program Digimax for Windows.

Definition of a positive sample.The definition of as circulating tumor cell (CTC) was based on the criteria of ISHAGE (Borgen et al., 1999), morphology of a cell with a nucleus, cytoplasm positive for CEA (Fig. 1). A primary CTC was defined as that detected before primary treatment and a secondary CTC was defined as that detected after surgical treatment. Clusters were defined as group of 3 or more cells and duplets as a group of 2 cells.

Histological Evaluation of the Primary Cancer. The surgical specimen was reviewed by a single pathologist, architectural and cytological features of each primary tumor were reviewed. Surgical specimens were fixed in formaldehyde, embedded in paraffin wax, and $4 \mu \mathrm{m}$ sections cut. Standard de-paraffination was carried out and the samples stained with hematoxillin and eosin.

\section{RESULTS}

Twelve patients had blood samples taken pre-surgery, 21 patients had blood samples taken between 2 and 4 months post-surgery and 26 patients had samples taken pre and post surgery, for a total of 59 patients. Of the 12 patients with only a pre-surgery sample, 7 died before a second sample could be taken and 7 were transferred to other hospitals. The 21 patients with only a post-surgery sample had been operated in the 4 months prior to starting the study.

Ten control patients with benign colorectal pathologies were used as controls. There were $31 \mathrm{female}$ and 28 male patients, with an average age of $63.3 \pm 13.0$ years, None of the control patients had CTCs detected.

Detection and characteristics of primary CTCs. In the 38 patients with a sample taken pre-surgery $34 / 38$ (85.9\%) had CTCs detected, the cells were markedly pleomorphic. There were cells with a high nuclear to cytoplasmic ratio (Fig. 1a) and also cells with moderate to abundant cytoplasm (Fig. 1e). Cell size variable considerably, many were larger than the surrounding leucocytes but there were also smaller cells (Fig. 1c). In the same patient there was a variation in form and size of CTCs (Fig. 1c). In patients with signet ring tumors, CTCs were seen to have a vacuolar pattern, presumably inclusions of mucin (Fig. 1e).

Eccentricity of the nuclear location within the cell cytoplasm was also a prominent feature of the CTCs. While the cytoplasm extends circumferentially around the nucleus (Figure 1a), many cells showed a cytoplasmic bulge on one side of the cell (Fig. 1d).

In patients with metastasis, groups of cells were detected of 3 or more cells, which were not seen in patients with non-metastastic cancer (Fig. 1a). However, groups of 2 cells were seen in both metastatic and non-metastatic cancer patients (Fig. 1b).

Detection and characteristics of secondary CTCs. In the 26 patients with samples taken before and after surgery, there were no differences cytomorphologically between primary and secondary CTCs. In patients were secondary CTCs were 

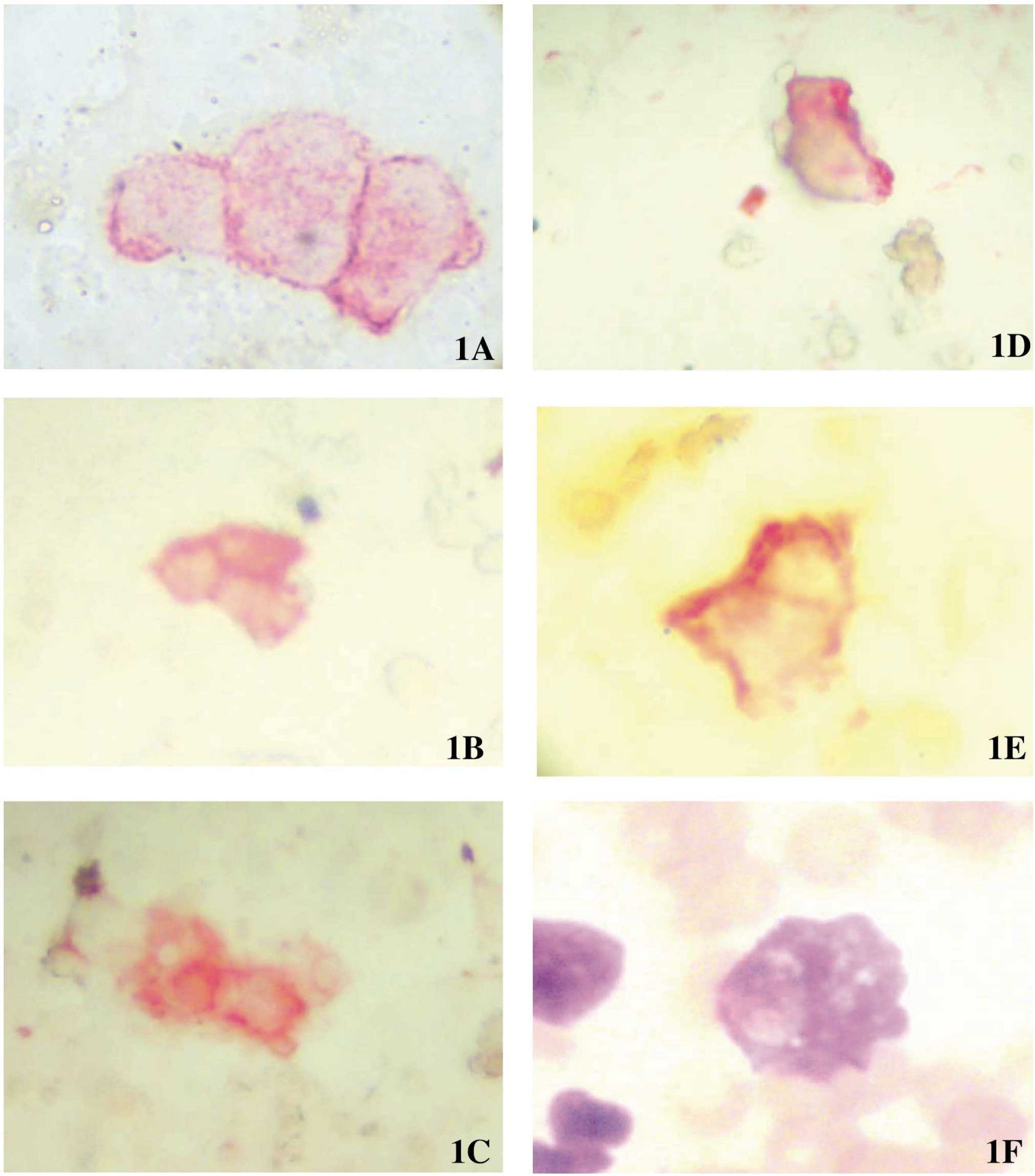

$1 \mathbf{D}$

B

$1 \mathrm{E}$

Fig. 1. Detection and characteristics of primary CTCs.

detected they exhibited the same cytomorphological characteristics as primary CTCs. Patients with metastasis continued to have groups of cells detected.

Cytomorphological evaluation of primary and metastatic tumor. Of the primary tumors 25 were classified as well differentiated, 19 as moderately differentiated, 10 as poorly 

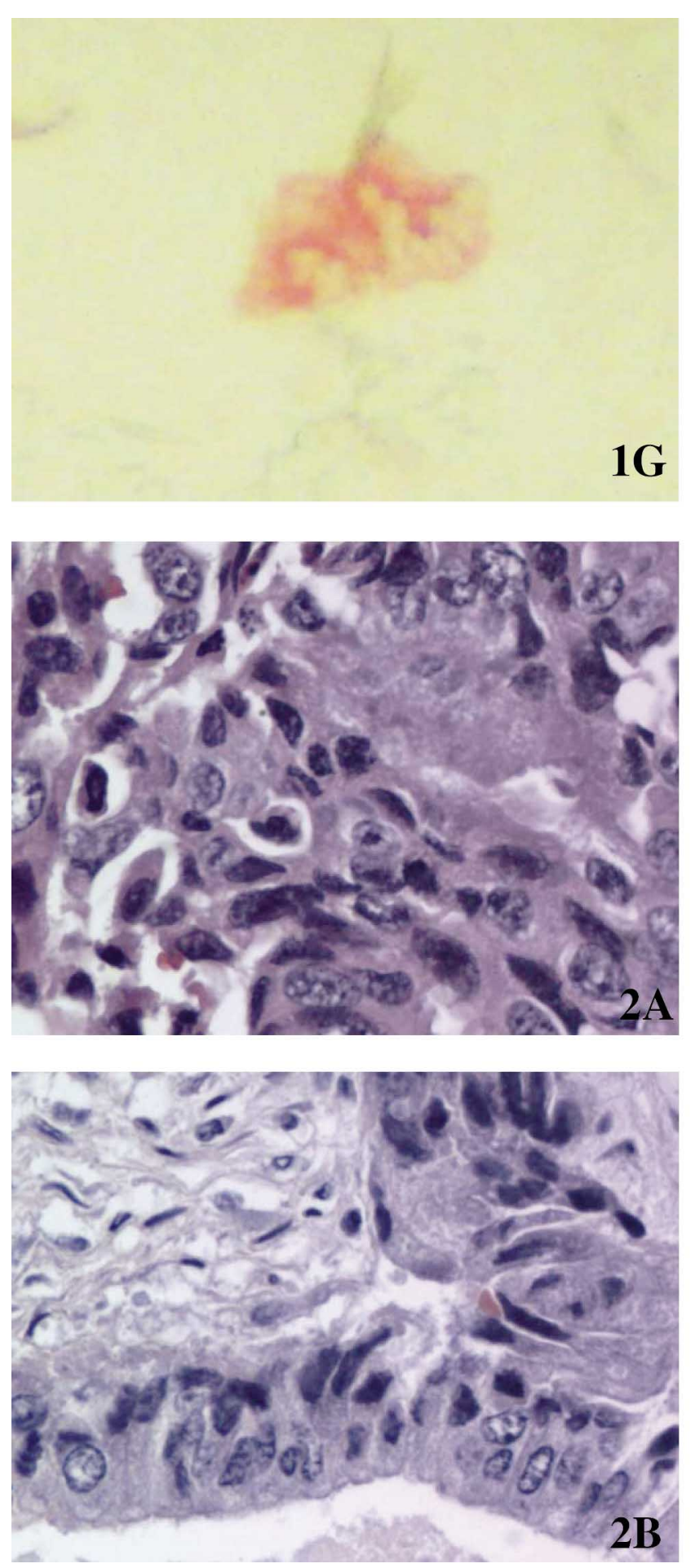

differentiated and 5 cases were classified as signet ring tumors. Figure 2a-d shows the typical morphology of the samples, with variation in nuclear size and abnormal gland formation. The abnormal glands were formed by columnar
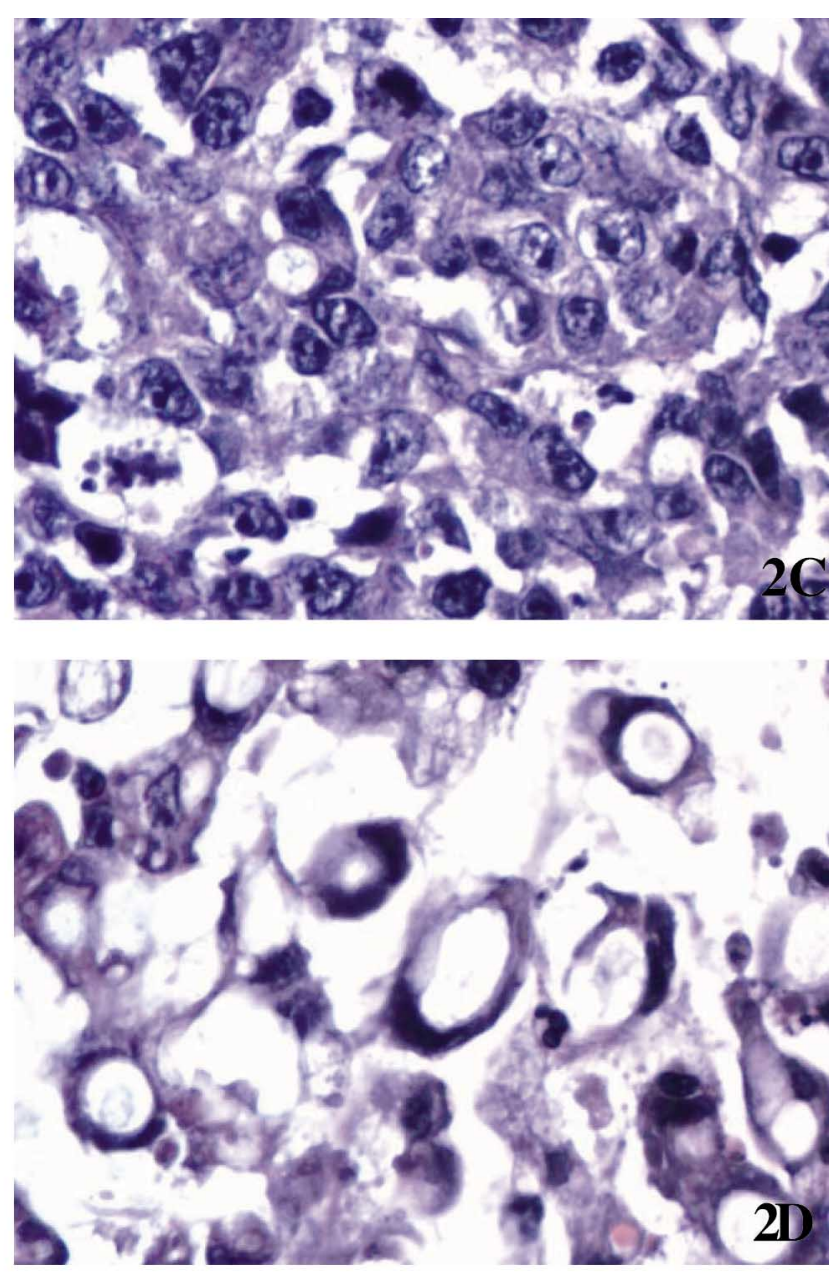

Fig. 2. Cytomorphological evaluation of primary and metastatic tumor.

cells with nuclear enlargement, hyperchromatism, elongation and stratification; although in the less well differentiated tumors some cells were more cuboidal. Individual cells varied in size, being larger than the surrounding normal cells, with a varying nuclear to cytoplasmic ratio. Some cells showing mitotic figures.

\section{Cytomorphological comparison of CTCs to primary and} metastatic tumors. In comparison with tissue biopsies of primary and metastatic tissues, the morphologic cell mix is similar to that of CTCs. However, while CTCs show a tendency towards eccentricities of the cytoplasm, their solid counterparts are columnar in shape. Tumors of the signet cell type have CTCs with "vacuoles" present representing the presence of mucin. CTCs tended to be rounded in their morphology rather than columnar or cuboidal and no mitotic figures were seen. 


\section{DISCUSSION}

Comparison of primary and metastatic colon tumor cells to CTCs showed similar cytomorphological features. CTCs maintain the same overall pleomorphism, with variations in size, shape and nuclear:cytoplasmic ratios. This supports the hypothesis that CTCs represent a random sampling of the many phenotypic cell types present in primary and metastatic disease, as proposed by Marrinucci et al. (2010), and the presence of CTCs with similar morphology as signet cells argues against that only particular subsets of tumor cells enter the circulation, such as very poorly differentiated "stem cell like" tumor cells, or only visibly dead or apoptotic tumor cells. That there were no differences in the morphology of CTCs in relation with the grade of differentiation of the primary or metastatic tumor, or between primary and secondary CTCs and that in general all were of a more rounded more suggests that in the blood environment without the presence of tissue support the cells take on a more spherical form rather than a columnar form. This has been documented in other tumors where CTCs tended to rounded or oval in shape (Molnar et al.; Marrinucci et al., 2007).

Clusters of cells were only seen in patients with metastatic cancer, before and after surgery and probably represent the higher tumor burden; groups of 2 cells were seen in both non-metastatic and metastatic disease.

The morphological evaluation of cells from different malignancies may contribute to our understanding of the metastatic process, and the appearance and variability of these features of the CTCs will be important for pathologists. The presence of CTCs in patients with non-metastatic disease, as defined by radiological imaging, represents residual disease and a higher risk of future relapse. It is possible that patients with duplets have a higher risk of relapse than those with single CTCS detected, but as yet there are not studies to confirm this hypothesis.

Using standard methodology in a routine immunocytochemcial laboratory of a general hospital it is possible to provide a service for the detection of CTCs without the necessity of high cost technology. That the detection of CTCs has clinical utility has been shown in patients with metastatic disease in terms of overall survival and response to treatment. Currently, studies are underway in patients with non-metastatic disease. With these methods the detection of CTCs may serve as a real time, easy accessible "biopsy" of an active tumor in a specific patient.

\section{ACKNOWLEDGEMENTS}

Mrs. Ana María Palazuelos de Murray for her help in the writing of this manuscript and Mrs. Erika Barriga auxillary nurse, Proctology Hospital de Carabineros de Chile.

MURRAY, N. P.; Albarran, R-C. V.; PÉReZ, O. G.; RUIZ, M. A.; PORCELL, E. J. \& CASTILLO, A. A. M. Citomorfología de las células tumorales circulantes y células agrupadas en pacientes Chilenos con cáncer colo-rectal. Int. J. Morphol., 30(3):834-839, 2012.

RESUMEN: El objetivo de este trabajo fue determinar las características cito-morfológicas de las células tumorales circulantes (CTCs) en pacientes con cáncer colo-rectal y compararlas con la cito-morfología del tumor primario y de las metástasis. CTCs fueron obtenidas de la sangre venosa usando centrifugación diferencial y detectadas utilizando inmumocitoquímica estándar con un anticuerpo monoclonal contra el antígeno carcino-embrionico. Las CTCs primarias fueron definidas como aquellas detectadas antes de la cirugía, y las CTCs secundarias aquellas detectadas después de la cirugía. Las piezas quirúrgicas fueron analizadas con métodos histológicos estándares con hematoxilina y eosina. Las CTCs primarias y secundarias se mantengan las mismas características cito-morfológicas que el tumor primario, con una grande variabilidad pleomorfica entre los diferentes pacientes. No hubo diferencias entre CTCs primarias y secundarias en términos de su morfología. Las CTCs detectadas en pacientes con tumores tipo anillo en sello tuvieron la presencia de inclusiones de mucina. CTCs agrupadas en 3 o más células solamente fueron detectadas en pacientes con metástasis, mientras la detección de CTCS en grupos de 2 células fueron detectadas en pacientes con o sin metástasis. Este estudio demuestra un análisis inicial de los hallazgos citomorfológicos de las CTCs en pacientes Chilenos con cáncer colo-rectal, y la base para investigaciones futuras acerca la significancia y potencial metastasica de las CTCs.

PALABRAS CLAVE: Células tumorales circulantes; Cáncer colo-rectal; Inmumocitoquímica. 


\section{REFERENCES}

Borgen, E.; Naume, B.; Nesland, J. M.; Kvalheim, G.; Beiske, K.; Fodstad, O.; Diel, I.; Solomayer, E. F.; Theocharous, P.; Coombes, R. C.; Smith, B. M.; Wunder, E.; Marolleau, J. P.; Garcia, J. \& Pantel, K. Standardization of the immunocytochemical detection of cancer cells in BM and blood: I. establishment of objective criteria for the evaluation of immunostained cells. Cytotherapy, 1(5):377-88, 1999.

Fidler, I. J. Metastasis: quantitative analysis of distribution and fate of tumor emboli labeled with 125 I-5-iodo-2'-deoxyuridine. J. Natl. Cancer Inst., 45(4):773-82, 1970.

Fidler, I. J. The relationship of embolic homogeneity, number, size and viability to the incidence of experimental metastasis. Eur. J. Cancer, 9(3):223-7, 1973.

Glaves, D. Correlation between circulating cancer cells and incidence of metastases. Br. J. Cancer, 48(5):665-73, 1983.

Jonas, S.; Windeatt, S.; O-Boateng, A.; Fordy, C. \& Allen-Mersh, T. G. Identification of carcinoembryonic antigen-producing cells circulating in the blood of patients with colorectal carcinoma by reverse transcriptase polymerase chain reaction. Gut, 39(5):717-21, 1996.

Leather, A. J.; Gallegos, N. C.; Kocjan, G.; Savage, F.; Smales, C. S.; Hu, W.; Boulos, P. B.; Northover, J. M. \& Phillips, R. K. Detection and enumeration of circulating tumour cells in colorectal cancer. Br. J. Surg., 80(6):777-80, 1993.

Marrinucci, D.; Bethel, K.; Bruce, R. H.; Curry, D. N.; Hsieh, B.; Humphrey, M.; Krivacic, R. T.; Kroener, J.; Kroener, L.; Ladanyi, A.; Lazarus, N. H.; Nieva, J. \& Kuhn, P. Case study of the morphologic variation of circulating tumor cells. Hum. Pathol., 38(3):514-9, 2007.

Marrinucci, D.; Bethel, K.; Lazar, D.; Fisher, J.; Huynh, E.; Clark, P.; Bruce, R.; Nieva, J. \& Kuhn, P. Cytomorphology of circulating colorectal tumor cells:a small case series. J. Oncol., 2010:861341, 2010.

Molnar, B.; Ladanyi, A.; Tanko, L.; Sréter, L. \& Tulassay, Z. Circulating tumor cell clusters in the peripheral blood of colorectal cancer patients. Clin. Cancer Res., 7(12):4080-5, 2001

Nagrath, S.; Sequist, L. V.; Maheswaran, S.; Bell, D. W.; Irimia, D.; Ulkus, L.; Smith, M. R.; Kwak, E. L.; Digumarthy, S.; Muzikansky, A.; Ryan, P.; Balis, U. J.; Tompkins, R. G.; Haber, D. A. \& Toner, M. Isolation of rare circulating tumour cells in cancer patients by microchip technology. Nature, 450(7173):1235-9, 2007.

Sastre, J.; Maestro, M. L.; Puente, J.; Veganzones, S.; Alfonso, R.; Rafael, S.; García-Saenz, J. A.; Vidaurreta, M.; Martín, M.;
Arroyo, M.; Sanz-Casla, M. T. \& Díaz-Rubio, E. Circulating tumor cells in colorectal cancer: correlation with clinical and pathological variables. Ann. Oncol., 19(5):935-8, 2008.

\section{Correspondence to: \\ Nigel P. Murray \\ Hospital de Carabineros de Chile \\ Santiago \\ CHILE}

Email: nigelpetermurray@gmail.com

Received: 10-04-2012

Accepted: 27-06-2012 